\title{
SELECTIVE Distribution RESTRICTIONS IN THE EU COMPETITION LAW
}

\section{Accepted \\ 17. 8.2020 \\ Revised \\ 12. 10.2020 \\ Published \\ 21. 12.2020}

UDC

347.776:061.1EU

Keywords anticompetitive agreements, block exemption regulation, competition law, online sales, selective distribution, vertical agreements.

\section{DARIA KOSTECKA-JURCZYK}

University of Wrocławski, Faculty of Law, Administration and Economics, Wrocław, Poland.

E-mail: daria.kostecka-jurczyk@uwr.edu.pl

CORRESPONDING AUTHOR

daria.kostecka-jurczyk@uwr.edu.pl

Abstract The dynamic development of digital technologies favours the rapid increase the popularity of electronic commerce, but at the same time causes an ever-stronger competitive pressure, prompting manufacturers and wholesalers to use various tools for controlling the sales system, especially prices. They often impose various restrictions on commercial partners (e.g. distributors) by preventing them from using certain sales channels. However, it is difficult to delimit the legality of such sales restrictions. It is very difficult to find an answer to the question of where the appropriate demarcation line should be drawn that determines the violation of competition rules, especially in online sales. Regulation $330 / 2010$ seems not to be tailored to the assessment of restrictions in online distribution channels. The aim of the article is to point out the lack of appropriate tools to assess the restrictions of internet sales. The article shows that there is currently no uniform approach by antitrust authorities, which in turn results in legal uncertainty. It seems that the amendment of Regulation 330/2010 should be considered and the market share threshold set out in it should be lowered, while at the same time ensuring that it will be an actual safe harbour for companies, including online distributors. 


\section{$1 \quad$ Introduction}

The constant growth of the online sales market brings many benefits both to sellers and buyers. It makes it easier for new sellers to enter the market because they do not have to incur significant investment costs in their own brick-and-mortar stores and can more effectively compete with other distributors who have been on the market for a long time. From the point of view of customers, the attractiveness of online shopping derives from the fact that it is easy to compare offers from different retailers, both for products from different as well as the same manufacturers. As a result, intra-brand competition (between distributors of the same brand) and interbrand competition (between competing products) rapidly increases (de la Mano, Jones, 2017:13-17). A special role in this context is played not only by sales platforms such as Amazon and eBay, but also by price comparison engines and algorithms. Furthermore, authorized retailers using the manufacturer's brand have the possibility of advertising on Google and other search engines (Gal, Elkin-Koren, 2017: 26; Lendle, Olarreaga, Schropp, V'ezina, 2012: 5). On the one hand, although online sales platforms make it easier to reach the customer, on the other hand a significant disadvantage is they increase the pressure to lower prices. Therefore, in an effort to offset this disadvantage, manufacturers try to influence online sales by imposing various restrictions on their distributors that can serve to ensure high-quality distribution. However, these restrictions can also serve to protect their traditional selling areas and affect the overall price level.

Manufacturers use digital tools (including algorithms and software) to monitor retailers' prices in online stores. At the same time, they strive to stabilize the price level. They also try to maintain minimum prices, especially when distributors lower the recommended price (Botteman, Barrio, 2019: 521; Winter, 2018: 184). As a result, they violate competition law rules. Article 101(1) of the Treaty on the Functioning of the European Union (hereinafter TFEU) prohibits "all agreements between undertakings, decisions by associations of undertakings and concerted practices which may affect trade between Member States and which have as their object or effect the prevention, restriction or distortion of competition within the internal market". Some practices raise much controversy, as it often is difficult to classify them unambiguously as anticompetitive within the meaning of Article 101 
TFEU. Examples include the cases Coty Gemany, ${ }^{1}$ Asics ${ }^{2}$ and Guess, ${ }^{3}$ in which manufacturers used various tools to limit online sales to certain distributors, especially third-party platforms such as Amazon and e-Bay. In these cases, the restrictions imposed on distributors were justified by the need to maintain a selective sales system.

The aims of the article are both to draw attention to the present lack of appropriate tools to assess the restrictions of Internet sales and to analyse the lack of uniformity of jurisprudence in cases concerning online sales restrictions. The article has been divided into six parts. The first part presents arguments justifying the limitations of online sales. Parts three through five analyses various online sales restrictions and case law of national courts and the CJEU based on the cases of Coty Germany, Asics and Guess. The next part of the work consists of considerations of admissible and prohibited sales restrictions. The analysis of these limitations is based on Commission Regulation (EU) No 330/2010 of 20 April 2010 on the application of Article 101(3) of the TFEU to categories of vertical agreements and concerted practices $^{4}$ (hereinafter: Regulation 330/2010) and the Commission Guidelines on Vertical Restraints. ${ }^{5}$ The last parts of the article contain the author's observations and conclusions.

\section{Selective sales system as a justification for limiting online sales}

A selective distribution system is mainly used for the sale of luxury or technologically advanced goods $^{6}$, as well as other high-quality products $^{7}$ the sale of which, due to their prestigious nature, requires a special "setting". ${ }^{8}$ This system also covers non-luxury products, but where the manufacturer organizes selective sales in an attempt to

\footnotetext{
${ }^{1}$ Case C-230/16, Coty Germany GmbH v Parfümerie Akzente GmbH, ECLI:EU:C:2017:941 (Coty Germany).

${ }^{2}$ Decision B2-98/11 from 26. 8. 2015 in case Bundeskartellamt v ASICS Deutschland GmbH, an English summary can be found at:

https://www.bundeskartellamt.de/SharedDocs/Entscheidung/EN/Fallberichte/Kartellverbot/2016/B2-98-

11.pdf?_blob=publicationFile\&v=2 (accessed: 2 . 7. 2020).

3 Commission decision from 17. 12. 2018 in case AT.40428 Guess, not yet published in OJ, available at: https://ec.europa.eu/competition/antitrust/cases/dec_docs/40428/40428_1205_3.pdf_accessed: 15. 4. 2020).

4 OJ EU L 102, 23. 4. 2010, p. 1.

5 OJ EU C 130, 19. 5. 2010, p. 1.

${ }^{6}$ Case 26/76, Metro SB-Großmärkte GmbH \& Co. KG v Commission of the European Communities, ECLI:EU:C:1977:167, para. 20 (Metro I); case 210/81, Oswald Schmidt, trading as Demo-Studio Schmidt, v Commission of the European Communities, ECLI:EU:C:1983:277.

${ }^{7}$ Guidelines on Vertical Restraints, para. 175.

${ }^{8}$ Case T-19/92, Groupement d'achat Edouard Leclerc v Commission of the European Communities, ECLI:EU: T:1996:190, para. 109 (Leclerc v Commission).
} 
achieve a higher profit margin by trying to cast certain products in the customer's mind as both "special and better" than similar products manufactured by competitors (Robertson, 2012a: 135; Robertson 2012b: 182). In the case of such products, the choice of the sales channel is influenced by the risk of losing exclusivity or luxury. For customers buying such products, the key is the image (reputation) of the brand and the ability to purchase with "appropriate setting" in brick-and-mortar stores. ${ }^{9}$ Without them, a product could be perceived as "cheap", "common", "mass" or "out of fashion". For this reason, it is important that the distributor meets the relevant requirements set by the manufacturer as to the location of the store, the aesthetic and functional display of products on the retail space, the substantive knowledge of the salespersons, service quality, etc. Specialized selective distributors have a strong influence on creating the image of a product or brand because they have the appropriate knowledge and experience that producers or suppliers often lack (Velz, 2011: 242). The selective sales system is an alternative to the relatively costly vertical integration of a producer of a specific good that could provide salesrelated services through its own distribution channels (Knibbe, 2012: 451). The organization and functioning of the distribution system may also be a significant element of qualitative competition.

In a selective distribution system, "approved distributors do not sell or purchase goods from wholesalers or retailers outside the official network" regardless of the geographic scope of the system. This approach is designed to avoid the risk that unauthorized distributors operating outside the selective distribution system could purchase products from members of the selective distribution system and then resell them to other unauthorized distributors in the area where the selective distribution system is in place (Coumes, Wilson, 2010: 440). From the point of view of competition law, selective sales systems in which the manufacturer, based on certain characteristics selects a distributor and excludes all others from the system, may favour the restriction of competition. ${ }^{10}$

\footnotetext{
${ }^{9}$ In many judgments, the EU Courts emphasized the importance of non-price aspects of competition. See case 99/79, SA Lancôme and Cosparfrance Nederland BV v Etos BV and Albert Heyn Supermart BV, ECLI:EU:C:1980:193; case 31/80, NV L'Oréal and SA L'Oréal v PVBA "De Nieuwe AMCK", ECLI:EU:C:1980:289 (L'Oréa); case Leclerc v Commission; case C-306/96, Javico International and Javico AG v Yves Saint Laurent Parfums SA (YSLP), ECLI:EU:C:1998:173; and case Metro I, para. 21.

${ }^{10}$ Case Metro I, para. 20.
} 
The widely discussed decisions of various antitrust authorities in the Coty Germany (CJEU) and Asics (German Federal Court of Justice) and Guess (European Commission) raised question about permissible restrictions on online sales (Zelger, 2018: 452). However, they did not answer the question whether restricting the possibility of selling through online platforms belonging to third parties (not distributors) should be treated as limiting competition within the meaning of Article 101(1) TFEU. In order to answer this question, we will analyse the three cases mentioned above (Coty Germany, Asics and Guess), where the selective distribution system at issue was supposed to justify restrictions on sellers.

\section{Restriction of sales through third-party platforms in the Coty Germany case}

Coty Germany $\mathrm{GmbH}$ is a leading distributor of luxury cosmetics in Germany. It sells products of certain brands that are generally recognized as prestigious. The other party was Akzent $\mathrm{GmbH}$, an authorized retailer of Coty brands for many years. Coty contended that the sale of luxury cosmetics through such third-party platforms that are not its distributors (such as Amazon) undermines the luxury image of cosmetics and accordingly banned sales through such platforms. However, Akzent $\mathrm{GmbH}$ did not want to limit online sales of products purchased from Coty, nor did it want to limit sales to only one online channel - parfumdreams.de (as suggested by Coty). Therefore, Akzent did not sign the contract and started selling through Amazon. Coty sued Akzent GmbH for its policy of selling its luxury products, because it was unacceptable for her. The domestic court in Frankfurt (Main) dismissed the complaint in the first instance ${ }^{11}$ but in the course of the appeal proceedings the Higher National Court applied for a preliminary ruling by the CJEU. ${ }^{12}$

The CJEU held that the prohibition of using such platforms is justified if a company uses a selective distribution system. ${ }^{13}$ Such a prohibition should serve to protect the brand image. The CJEU confirmed its previous jurisprudence that although it is true that selective distribution systems affect competition in the internal market in certain

\footnotetext{
${ }^{11}$ Judgment of the National Court in Frankfurt (Main) from 31. 7. 2014 in case 2-030 128/13.

${ }^{12}$ Order of the Higher National Court in Frankfurt (Main) from 19. 4. 2016 in case 11 U 96/14 (Kart.).

${ }^{13}$ Case Coty Germany, para. 46.
} 
circumstances, they are not prohibited under Article 101(1) TFEU. ${ }^{14}$ According to the CJEU, the creation of a selective distribution system to ensure the prestige of luxury goods is, in principle, compatible with competition law. ${ }^{15}$ Protecting the prestige character should help to ensure the appropriate quality of products. ${ }^{16}$ This is also consistent with the jurisprudence of the CJEU on intellectual property law, where the quality of prestigious goods is not that important in itself. It is also important to display products in a luxurious way, which increases the brand's prestige. ${ }^{17}$ The CJEU sees ensuring an appropriate brand image as a legitimate aim of restricting competition, although in its judgment in the case Pierre Fabre, the Court stated that the protection of prestige cannot justify a restriction of competition. ${ }^{18}$

The Coty Germany judgment shows that the CJEU seeks to distinguish between luxury goods and other branded products. There, the CJEU referred to its judgment in the Copad/Dior case ${ }^{19}$ and referred to a direct link with intellectual property law (trademark law) as well as the assessment of well-known brands by exploiting the product's reputation. In practice, products with an aura of luxury are typically branded. Luxury products should be understood as those that are acquired not only for their material value, but also for their prestigious nature. ${ }^{20}$

It should be emphasized that in its judgment the CJEU examined and ruled upon only those Coty cosmetics which were assigned the attributes of luxury goods and did not take into account products that were not covered by the reference for a preliminary ruling. The criteria that the CJEU applied to luxury products should also apply to other high-quality branded products (Havu, Zupancic, 2019: 235; Szot, Amza, 2018: 250). According to the CJEU, selective distribution systems and a ban on the use of third-party platforms help to ensure the high quality of products. Brand confidence is weakened when the right quality is not ensured. For this reason, some sellers of high-value products are prohibited from selling through different

\footnotetext{
${ }^{14}$ Case Metro I, 20-21; case C-439/09, Pierre Fabre Dermo-Cosmétique SAS v Président de l'Autorité de la concurrence and Ministre de l'Économie, de l'Industrie et de l'Emploi, ECLI:EU:C:2011:649, para. 41 (Pierre Fabre); case 75/84, Metro SB-Großmärkte GmbH \& Co. KG v Commission of the European Communities, ECLI:EU:C:1986:399, para. 40 (Metro II).

15 Case Coty, para. 36.

16 Case Coty, para. 28.

17 Case C-59/08, Copad SA v Christian Dior couture SA, Vincent Gladel and Société industrielle lingerie (SIL), ECLI:EU:C:2009:260, para. 24 (Copad/Dior); case C-337/95, arfums Christian Dior SA and Parfums Christian Dior BV v Evora BV, ECLI:EU:C:1997:517, para. 45.

18 Case Pierre Fabre, paras 45-47.

${ }^{19}$ Case Copad/Dior, para. 24.

${ }^{20}$ Case Coty Germany, para. 25.
} 
platforms under a selective distribution system. This is in line with competition law generally (Colangelo, Tor ${ }^{\mathrm{ti}}$, 2018: 89). The ban on selling via platforms could even be interpreted more broadly, if economically justified, to encompass non-luxury products that are judged by consumers as high-quality. Indeed, such a broad interpretation was applied by the Advocate General N. Wahl, ${ }^{21}$ who analysed not only the selective system of selling luxury goods, but also assessed the advantages of such a system for products with special properties, which in the opinion of customers have an additional value (high quality) and an exclusive character.

However, the content of the Coty judgment does not allow for an unequivocal answer to the question whether the supplier can prohibit its distributors from selling its goods over the Internet. First of all, the CJEU did not distinguish between Amazon as platform and distributor. This is likely due to the fact that Amazon is not a Coty distributor. The situation is different when the manufacturer works directly with the third-party platform as a distributor (when Amazon is a part of a selective distribution system). In such cases the platform ban would prevent further cooperation between the producer and the distributor, which would constitute a violation of Article 101(1) TFEU.

\section{Selective Distribution Restrictions in ASICS case}

Selective distribution restrictions in the field of internet sales were also applied by ASICS Deutschland GmbH (ASICS), ${ }^{22}$ which prohibited its distributors not only from selling products on third-party platforms, such as Amazon, but also from cooperating with price comparison websites. Additionally, it prohibited distributors from using the ASICS trademark as keywords in internet advertising posted on thirdparty websites (e.g. in search engines). The ban on using the ASICS name on thirdparty websites has limited distributors from increasing the possibility of searching for their offer and thus acquiring customers.

\footnotetext{
${ }^{21}$ Opinion of Advocate General N. Wahl in case C-230/16,

http:/ / curia.europa.eu/juris/document/document.jsf;jsessionid=173661A0E04DB5F8049DB573A4A94559?text $=\&$ docid $=193231 \&$ pageIndex $=0 \&$ doclang $=\mathrm{EN} \&$ mode $=1$ st $\&$ dir $=\& o c c=$ first\&part $=1 \&$ cid $=12230904$ (accessed: 20. 7. 2020).

${ }^{22}$ Decision of 26. 8. 2015 in case B2-98/11 Bundeskartellamt v ASICS Deutschland GmbH, case summary is available at: https://www.bundeskartellamt.de/SharedDocs/Entscheidung/EN/Fallberichte/Kartellverbot/2016/B2-9811.pdf?_blob=publicationFile\&v $=2$ (accessed: 20.7 .2020$)$.
} 
The German Competition Authority (Bundeskartellamt, hereinafter referred to as BKartA) found it difficult to justify any of these restrictions given that they were similar to prohibitions. Because distributors were prohibited not only from advertising their own online store with the ASICS trademark but also from using price comparison websites selling via third party platforms, sellers had difficulties in expanding their customer base. These restrictions were deemed to be restrictions on competition. ${ }^{23}$ BKartA expressed the views both that ASICS products are not "luxury items" and that the ASICS brand lacks a signalling effect that would justify an individual exclusion when considering the need to protect the brand image. Consequently, BKartA concluded that the restrictions were not necessary either to maintain the specialized retailer system or to protect the ASICS brand image. ${ }^{24}$

The court stated that running shoes could not be considered "high value" or "luxury" products and found that the restrictions imposed on distributors by ASICS were not of a qualitative nature. ${ }^{25}$ Furthermore, these restrictions led to the foreclosure of the entire distribution channel, thus preventing retailers from selling online because they did not have access to the sales platform. ${ }^{26}$ The restrictions imposed by ASICS violated competition law not only because ASICS did not even attempt to establish quality standards to ensure that distributors only use pricing portals that do not have a negative impact on the manufacturer's brand, but also because the restrictions could not be considered to be proportionate measures. ${ }^{27}$

Even assuming that running shoes require a specific advertising environment, the court found that it was unclear why ASICS did not at least specify the quality requirements that comparison websites should meet. The court also rejected ASICS's argument that the use of these sites would involve significant costs, finding that it was unacceptable for ASICS to justify such restrictions with the purported aim of "protecting buyers from themselves". Moreover, the restrictions failed to address the so-called "free-riding" problem which arises when consumers visit brickand-mortar stores for consultation purposes and then buy online. The court noted that the prohibition of retailers from cooperating with price comparison sites was

\footnotetext{
${ }^{23}$ Ibidem, paras 254-255.

24 Ibidem, paras 260-267.

${ }^{25}$ Case VI-Kart 13/15 (V) of April 5, 2017, point 63. The reasons can be found in the German language text at: http://www.justiz.nrw.de/nrwe/olgs/duesseldorf/j2017/VI_Kart_13_15_V_Beschluss_20170405.html (accessed: 20. 7. 2020).

${ }^{26}$ Ibidem, para. 71.

${ }^{27}$ Ibidem, para. 72 .
} 
intended to limit sales to end users. ${ }^{28}$ This practice severely limited the seller's freedom in the field of online sales as it prevented passive sales to consumers. ${ }^{29}$

Contrary to the Coty case, in ASICS customers were not able to access the authorized dealers' online offer due to a combination of various restrictions. It is not possible to evaluate individual restrictions here, as each of them had a different purpose and justification. However, if we evaluate the entire package of restrictions, the conclusion reached is that cumulatively they prevented retailers from selling online, a situation the court held was incompatible with competition law. A broad package of restrictions was also introduced by the Guess group of companies.

\section{$5 \quad$ Online sales restrictions implemented by Guess}

In 2018, the Commission imposed a fine of 40 million euros against the companies Guess Inc., Guess Europa, B.V. and Guess Europe Sagl ("Guess”). ${ }^{30}$ This case concerned a number of anti-competitive behaviours on the part of Guess, but also included one that had not previously been the subject of the Commission's proceedings, namely, a restriction on the use of trademarks as keywords in Google AdWords. The Commission found that the Guess companies violated Article 101 TFEU through practices aimed at restricting designated distributors from selling. According to the Commission, those practices went beyond what was necessary for the operation of the selective distribution system. They consisted of:

- using the Guess brand names and trademarks for the purposes of online search advertising,

- selling online without a prior specific authorisation by Guess. The company had full discretion for this authorisation, which was not based on any specified quality criteria,

- selling to consumers located outside the authorised retailers' allocated territories,

- cross-selling among authorised wholesalers and retailers,

\footnotetext{
${ }^{28}$ Ibidem, paras 101-102.

${ }^{29}$ Ibidem, paras 14 and 23.

${ }^{30}$ Commission decision in case AT.40428 Guess.
} 
- independently deciding on the retail price at which distributors were to sell Guess products. ${ }^{31}$

Guess's distributors were allowed to sell products online, but were deprived of the ability to generate traffic to their websites through search engine advertising services. This severely restricted their ability to sell products. The Commission found these restrictions to be a distortion of competition by object. The restriction of internet advertising on search engines had a direct impact on retailers' sales volumes falling outside their contractual or operating territory, which resulted in market partitioning. This restriction also significantly reduced intra-brand competition between retailers. For this reason, the Commission concluded that such a restriction violates the prohibition of concluding competition-restricting agreements within the meaning of Article 101(1) TFEU. Most importantly, the decision sheds new light on the Commission's approach to the restrictions of search advertising. According to the Commission, Guess's intentions of reducing the competitive pressure on its own online retail sales and keeping advertising costs at a minimum were not justified. Consequently, by classifying Guess's restriction in AdWords as restricting competition 'by object', the Commission has signalled that brand owners may have difficulty justifying such restrictions under EU competition rules.

However, the Commission's approach in this matter is questionable. Regarding the limitation by object, its content, objectives and the economic and legal context must be taken into account. The assumption that this was a restriction by object means that the Commission has not objectively verified whether such conduct actually had any anti-competitive effect. This broad-based approach is worrying, especially when there may be other pro-competitive arguments to justify this kind of behaviour. For example, ad restrictions in keyword search results may be justified to prevent active sales to another territory, as long as the retailer is allowed to use the trademark in conjunction with a geographical indication or the language of its exclusive territory. A less draconian solution could be to allow the supplier to control pre-sale information and services through their own website to inform potential customers about the products, especially where quality aspects are an important differentiator from other brands in the market.

\footnotetext{
${ }^{31}$ Ibidem.
} 
In sum, it is difficult to agree with the Commission that AdWord restrictions intrinsically infringe competition law, as under certain circumstances they may have pro-competitive effects. The analysis of the Guess decision (similar to that discussed in Coty Germany and Asics) raises the question of what the appropriate criteria should be for qualifying certain restrictions as lawful under TFEU.

\section{Admissibility of selective sales restrictions}

In the Coty Germany case, the CJEU stated that a restriction of competition could only be considered in the case of a complete ban on online sales. This would result in foreclosure of all online customers. At the same time, it found that the ban on the use of online platforms does not constitute a significant restriction of competition within the meaning of Article 4 of Regulation 330/2010 because buyers through online platforms belong to the general group of online customers and are not separated from this group or divided into other subgroups. ${ }^{32}$ Only one of the sales channels is closed, which is in line with the nature of a selective distribution system.

Referring to the Metro I judgment, ${ }^{33}$ the CJEU found that the establishment and operation of selective sales systems is compatible with competition law, if the seller is selected on the basis of objective criteria and on a non-discriminatory basis. In addition, requirements must be formulated to ensure quality, as well as a warranty and guarantee of professional service for the sales network. ${ }^{34}$ These criteria must be tailored so as not go beyond what is necessary. Clauses prohibiting online sales are unacceptable unless the prohibition is explicitly stated and de facto exists. ${ }^{35}$ The ban on the use of online platforms does not restrict competition as long as it does not reduce the customer group or limit passive sales. The group of customers includes internet buyers who do not constitute a separate group of buyers (through platforms). Given the price differentiation on the internet, as well as the high price transparency, it cannot be assumed that potential customers are not informed in detail about alternative offers until they find the product in the online store. The ability to check prices is very easy and fast. In practice, the decision to buy does not depend on whether a specific product is also offered via the internet platform, but on other factors such as product quality and price, delivery and return conditions

\footnotetext{
${ }^{32}$ Case Coty Germany, para. 66.

${ }^{33}$ Case Metro I, paras 20-21.

${ }^{34}$ Ibidem, point 20; case L'Oréal, para. 15.

${ }^{35}$ Case Pierre Fabre, para. 47.
} 
(mainly the lack of fees for these services). Therefore, there is no separate group of buyers through platforms.

A similar view was expressed by the Higher National Court of Karlsruhe in 2009, which observed that the ban on the sale of branded products by the seller at a later stage of distribution does not infringe competition, if it concerns sales via platforms belonging to third parties, such as eBay. The seller can take steps to prevent a sale at a very low price on eBay. ${ }^{36}$ Objective criteria for selecting the auction platform are important here. The supplier (producer) may prohibit sales through internet platforms on a non-discriminatory basis. Therefore, the criteria for selecting resellers must be formulated in such a way that the selective sales system is not discriminatory. This view is also confirmed by the judgment of the Court in Munich, which additionally indicates that a clause prohibiting the use of third-party internet platforms may be compatible with competition law, as there is no restriction of the customer group within the meaning of Article 4(b) Regulation 330/2010.37 This article states that it is unacceptable to restrict active sales into the exclusive territory or to an exclusive customer group reserved to the supplier or allocated by the supplier to another buyer, where such a restriction does not limit sales by the customers of the buyer. The group of customers using the online auction platforms cannot be limited within this group. ${ }^{38}$

A different view was expressed by the Higher National Court in Schleswig, which found decisive that the ban on the use of platforms significantly limits specific sales opportunities, because it de facto reduces the number of potential customers. In the court's opinion, the mere artificial limitation of a group of customers, and not only the exclusion of a specific group, leads to a significant restriction of competition. ${ }^{39}$

In turn, the National Court in Berlin found that the general prohibition of selling goods via eBay does not contain any qualitative features as to the choice of the reseller and therefore violates the competition law. ${ }^{40}$ The court reasoned that since it is difficult to justify such a prohibition it therefore is discriminatory. A similar view is expressed by the German Antimonopoly Office (Bundeskartellamt), which claims

\footnotetext{
${ }^{36}$ Judgment of the National Court in Berlin from 19. 9. 2013 in case 2 U 8/09 Kart., para. 48.

${ }^{37}$ Judgment of the National Court in Munich from 9. 7. 2009 in case U (K) 4842/08, para. 27.

38 Ibidem, para. 30.

${ }^{39}$ Judgment of the National Court in Schleswig-Holstein from 5. 6. 2014 in case 16 U Kart. 154/13, para. 82.

${ }^{40}$ Judgment of the National Court in Berlin from 21. 4. 2009 in case $160729 / 09$ Kart., para. 38.
} 
that the ban on selling through online stores violates Article 101(1) TFEU and is not subject to exemption. ${ }^{41}$

The judgment of the National Court in Berlin and the quoted view of the German Antimonopoly Office should be considered rational in the case of goods whose nature does not justify selective sale. However, it does not seem appropriate to transform these views into a general rule allowing antitrust authorities to sanction restrictions on the participation of third-party platforms in the sales process in every case. Rather, sanctioning should be strictly limited to cover only the unacceptable restrictions specifically listed in Regulation 330/2010.

\section{$7 \quad$ Unacceptable restrictions on online sales}

Article 4 of Regulation 330/2010 lists the restrictions that are not block exempted. This provision covers, i.a. restrictions on internet sales, including territorial. The most severe restrictions mentioned in this provision concern the division of the market according to geographic or subjective criteria (mainly the limitation of active or passive sales). Suppliers may limit active sales by buyers to territory or customer groups that have been allocated to another buyer (reseller) or that the supplier has reserved for itself (Article 4 (b)(1) of the Regulation 330/2010).

Active sales means an aggressive approach to individual customers, including sending information by e-mail that was not ordered by customers, or an active approach to a specific group of customers in certain areas through advertising in the media, on the internet or other promotions aimed at that group of customers or customers in specific areas. According to Article 4 b) Regulation 330/2010, suppliers can limit active sales into the exclusive territory or to an exclusive customer group if such a restriction does not limit sales by the customers. It means that an exclusive distributor is protected against active selling in its territory or to its customer group by all buyers of a specific supplier in the EU.

By contrast, passive sales means responding to the needs of individual customers, including the supply of goods and services to these customers. ${ }^{42}$ Passive sales also

\footnotetext{
41 Bundeskartellamt decision from 19.08.2014 in case B3-137/12 - Adidas, case summary is available at: https://www.bundeskartellamt.de/SharedDocs/Entscheidung/EN/Fallberichte/Kartellverbot/2014/B3-13712.pdf?_blob=publicationFile\&v=2 (accessed: 20.7 .2020$)$.

${ }^{42}$ Ibidem, para. 51; case Pierre Fabre, para. 54.
} 
include advertising or promotions that reach (exclusive) customers in areas reserved for other distributors or customer groups. The rules for the protection of "exclusive territories or customer groups" must allow for passive sales to such territories or to such customer groups. The Commission explains that having a website, for example, is a form of passive selling as it can be accessed from various places. So, a website is seen as a way of giving customers access to the distributor. If the sale is made via the website and it is possible to deliver the goods, then this should be classified as a passive sale. In addition, the availability of different language options used on the website is also considered passive selling (Sean Morris, 2011: 198).

There are four types of hardcore restrictions in the field of passive selling. The first is to agree that an exclusive distributor will avoid customers located in another area where a separate distributor operates by preventing them from using its website or automatically redirecting them to the site of another distributor (or exclusive distributor). The second is the use of credit card details, especially identity, to end (interrupt) an online transaction by the exclusive distributor as soon as it turns out that the buyer's address does not coincide with the exclusive distributor's area. The third form is when the exclusive distributor agrees to limit its sales in brick-andmortar stores in relation to total online sales. ${ }^{43}$ The fourth form is when the distributor agrees to pay a higher price for the products he intends to resell online than the price for the products sold in stores. ${ }^{44}$

Other unacceptable restrictions also include the fixing of the resale price, i.e. an agreement or concerted practice to fix a reserve or fixed price. Fixing a resale price can seriously restrict competition as it promotes greater market transparency and therefore makes it easier to verify that the supplier is not breaking out of the agreement and lowering his price. In addition, this practice eliminates intra-brand competition and may facilitate collusion between buyers at the distribution level. It may also weaken the competitive pressure between producers if they use the same distributors and a uniform (the same) resale price is applied by all or many of them. Fixing the resale price may be acceptable to manufacturers wishing to limit downward pressure on subsequent distributors (de la Mano, Jones, 2018: 14). Finally, the fixing of the resale price by producers with significant market power may contribute to foreclosing smaller competitors from entering into the market. It can

\footnotetext{
${ }^{43}$ Guidelines on Vertical Restraints, para. 52(c).

44 Ibidem, para. 52(d).
} 
also have a negative impact on the entry or expansion of retailers who wish to benefit from scale of sales at reduced prices.

Competition may also be restricted as a result of a combination of selective distribution and non-compete obligations, as other suppliers may be foreclosed. ${ }^{45}$ This applies to situations where a leading supplier not only applies quality criteria, but imposes certain additional obligations on its distributors, such as an obligation to maintain a minimum shelf area for its products or to ensure a certain volume of sales (the distributor sells a certain amount of goods or services that constitute percentage of its total sales volume). However, the Commission considers that the risk of distortion of competition in such situations is relatively small where the market share of the supplier in which selective distribution is used is below 50 percent or more than 50 percent, but the share of the five largest suppliers in this market exceeds 50 percent (CR5). ${ }^{46}$

The foreclosure effect may also arise from the application of qualitative criteria. This may have the effect of restricting the sale of goods further down the distribution chain via third-party online platforms. However, it is difficult to clearly define when there is a risk of violating Article 101 TFEU.

\section{$8 \quad$ Observations}

The organization of the online distribution system can undoubtedly force certain restrictions on sales through various channels. It seems that such restrictions should be allowed if they fall within the scope of Regulation 330/2010. First of all, this applies to a situation where passive sales are not limited and the turnover threshold is met. According to Article 3(1) of Regulation 330/2010, this threshold may not exceed 30 percent for any of the market parties (neither the supplier nor the recipient). In the cases discussed above, this threshold was not exceeded, yet sanctions were imposed on companies. As for the limitation of passive sales, it was a problem practically only in the Guess case and justified the imposition of sanctions. However, the Commission looked at Guess's practices more broadly and concluded that the imposition of a fine would justify the remaining restrictions on distributors. The analysis of the cases discussed above lead to the conclusion that the provisions

\footnotetext{
45 Ibidem, para. 183.

${ }^{46}$ Ibidem, paras 183 and 179.
} 
of Regulation 330/2010 do not provide legal certainty for companies. Therefore, it is worth considering eliminating (not renewing) this regulation in the future, especially because it will expire on 31 May 2022.

There is currently a debate about the need to develop a new model for the assessment of anticompetitive agreements on digital markets that emphasizes the need to maintain open markets and prevent the concentration of e-commerce in the hands of only a few players, i.e. manufacturers themselves, some large distributors and even fewer leading platforms, which will significantly reduce customer choice. ${ }^{47}$ One of the proposed solutions is to establish a new approach to the assessment of vertical agreements on online sales markets. However, the most important consideration seems to be the need for improvement of economic tools for assessing infringement of competition law in such markets (Mancini, 2019: 3).

The Commission should consider implementing guidelines indicating situations in which it would be possible to exempt vertical agreements on online markets from the prohibition contained in Article 101(1) TFEU. Guidelines are not binding; they only provide guidance. However, such guidance would have a positive impact upon entrepreneurs in the sense they would be more cautious when deciding to impose restrictions on distribution channels. Additionally, they would not be disappointed afterwards that sanctions are imposed on them despite meeting some criteria set out in secondary legislation. From the point of view of antitrust authorities, this would also have the advantage of avoiding a rigid decision-making framework.

The second solution that could be considered is to lower the market share threshold to, for example, 20 percent. The current threshold of 30 percent for each of the sales partners entering into a vertical agreement appears too high. Such a market share may entail market power on some markets and sales restrictions may be strongly motivated by a desire to weaken certain distributors or even exclude them from the

\footnotetext{
47 See: UK Report: Digital Competition Expert Panel (2019), Unlocking digital competition, https://assets.publishing.service.gov.uk/government/uploads/system/uploads/attachment_data/file/785547/un locking_digital_competition_furman_review_web.pdf (accessed: 7. 4. 2020); Stigler Report: Committee for the Study of Digital Platforms (2019), Draft Report: Committee for the Study of Digital Platforms - Market Structure and Antitrust Subcommittee, George J. Stigler Center for the Study of the Economy and the State, The University of Chicago Booth School of Business, https://research.chicagobooth.edu/-/media/research/stigler/pdfs/marketstructure---report-as-of-15-may-2019.pdf (accessed: 7. 4. 2020); EU Report: J. Crémer, Y.-A. de Montjoye and H. Schweitzer (2019), Competition policy for the digital era, European Commission, https://op.europa.eu/en/publication-detail/-/publication/21dc175c-7b76-11e9-9f05-01 aa75ed71a1/language-en (accessed: 7. 4. 2020).
} 
market. Lowering the market share threshold to 20 percent should prove to be a strong barrier against competition authorities interfering in vertical agreements. The market share of 20 percent is close to the de minimis exemption level under the Commission's Notice on Agreements of Minor Importance form on August 30, 2014.48 This Notice stated that the Commission will not normally initiate proceedings under Article 101(1) TFEU where the parties' combined market shares on the relevant product market do not exceed 15 percent, irrespective of whether they are active in the same geographic market. The size of the market share and its calculation plays a decisive role in practice. Currently, companies are not sure whether they will use the safe harbour even if the market share threshold is not met. The threshold set in regulation 330/2010 does not always allow the agreement to be excluded from the prohibition contained in Article 101(1) TFEU. For this reason, it is worth considering lowering its level and treating it as a guarantee of excluding the agreement from the prohibition contained in Article 101(1) TFEU, with the exception of the cases referred to in Article 4 of Regulation 330/2010. Doing so would increase legal certainty, especially in new technology markets and online sales markets, where universal solutions have not yet been developed.

\section{Conclusions}

The Coty Germany, Asics and Guess cases concern various restrictions imposed in selective distribution systems. Even though the subject of restrictions was central in all three cases, the CJEU and German Competition Authority has not clearly ruled (provided clear guidance) on the question of what restrictions are permissible in the context of online sales. In all of this decisions is the lack of clarity negatively impacts business because it fears negative repercussions (i.e. sanctions/penalties) if it guesses wrong about how the competition authorities and the CJEU will interpret Article 101(1) TFEU in this particular context. The analyse of above cases even raise the question of when the restriction of online sales in selective distribution systems constitutes a restriction of competition under Article 101(1) TFEU. There are no clear guidelines on how to assess restrictions on online sales, which results not only the lack of a uniform approach but also the lack of legal certainty. Most significantly, it is not clear at what point the restrictions on online sales reduce the distributor's ability to sell to the extent that should be considered as restriction of passive sales under Regulation 330/2010.

\footnotetext{
${ }^{48}$ OJ EU C 291, 30. 8. 2014, p. 1.
} 
Therefore, it is important to consider in the future the development of new methods of assessing vertical agreements on online markets or even lowering the market share threshold enabling exemption from the prohibition contained in Article 101(1) TFEU and ensuring that it will indeed provide a viable safe harbour.

\section{References}

Botteman, Y., Barrio, D. (2019) From Pierre Fabre to Coty and Beyond: How Far can Suppliers Ban Online Sales?, J.E.C.L. \& Practices, 10(9), pp. 519-531.

Colangelo, G., Torti, V. (2018) Selective Distribution and Online Marketplace Restrictions Under EU Competition Rules After Coty Prestige, European Competition Journal, 14(1), pp. 8-109.

Coumes, J. M., Wilson, K. (2010) New Rules on Supply and Distribution Agreements: Main Changes of the New System, European Competition Law Review, 31(11), pp. 439-441.

Crémer, J., de Montjoye, A., Schweitzer, H. (2019) Competition Policy for the Digital Era, European Commission, https://op.europa.eu/en/publication-detail/-/publication/21dc175c-7b7611e9-9f05-01 aa75ed71a1/language-en (accessed: 7. 4. 2020).

de la Mano, M., Jones, A. (2017) Vertical Agreements under EU Competition Law: Proposals for Pushing Article 101 Analysis, and the Modernization Process, to a Logical Conclusion, http://awa2018.concurrences.com/IMG/pdf/ssrn-id2930943.pdf (accessed: 15. 4. 2020).

Gal, M., Elkin-Koren, N. (2017) Algorithmic Consumers, Harvard Journal of Law \& Technology, 30(2), pp. 1-45.

Havu, K., Zupancic, N. (2019) Online Platforms and Selective Distribution: Coty Ruling Addresses Topical E-commerce Issues, European Law Review 2019, 44(2), pp. 222-237.

Knibbe, J. (2012) Selective Distribution and ECJ's Judgment in Pierre Fabre, European Competition Law Review, 2012, 33(10), pp. 450-451.

Lendle, A., Olarreaga, M., Schropp, S., Vézina, P. L. (2012) There Goes Gravity: How eBay Reduces Trade Costs, The World Bank Poverty Reduction and Economic Management Network International Trade Department, Policy Research Working Paper 6253, pp. 1-44.

Mancini, J. (2019) Digital antitrust: An Emerging Consensus? Concurrences, 4, Art. N 92053, pp. $1-$ 11, https://www.concurrences.com/en/review/issues/no-4-2019/international/jamesmancini (accessed: 7. 4. 2020).

Robertson, V. H.S.E. (2012a) Online Sales Under the European Commission's Block Exemption Regulation on Vertical Agreements - Part 1, European Competition Law Review, 33(3), pp. 132-137.

Robertson, V. H.S.E. (2012b) Online Sales Under the European Commission's Block Exemption Regulation on Vertical Agreements - Part 2, European Competition Law Review, 33(4), pp. 179-184.

Sean Morris, P. (2011) Vertical Restraints and Parallel Trade: Selective Distribution and Article 101 of the Treaty on the Functioning of the European Union in Light of the Revised Rules on Vertical Agreements, University of La Verne Law Review, 32(2), pp. 185-255.

Stigler Report: Committee for the Study of Digital Platforms (2019) Draft Report: Committee for the Study of Digital Platforms - Market Structure and Antitrust Subcommittee, George J. Stigler Centre for the Study of the Economy and the State, The University of Chicago Booth School of Business, https://research.chicagobooth.edu/-/media/research/stigler/pdfs/marketstructure---report-as-of-15-may-2019.pdf (accessed: 7. 4. 2020).

Szot, P., Amza, A. (2018) Marketplaces Restrictions and Selective Distribution after Coty Germany, Yearbook of antitrust and Regulatory Studies, 11(18), pp. 241-284.

UK Report: Digital Competition Expert Panel (2019) Unlocking Digital Competition, https://assets.publishing.service.gov.uk/government/uploads/system/uploads/attachment_ 
data/file/785547/unlocking_digital_competition_furman_review_web.pdf (accessed: 7. 4. 2020).

Velz, M. (2011) Recent Developments in Selective Distribution, European Competition Law Review, 32(5), pp. 242-247.

Winter, R. A. (2018) Pierre Fabre, Coty and Restriction on Internet Sales: An Economist's Perspective, J.E.C.L. \& Practice, 9(3), pp. 183-187.

Zelger, B. (2018) Restriction of Online Sales and Vertical Agreements: Bundeskartellamt vs. Commission? Why Coty and Asics are compatible?, European Competition Journal, 14(2-3), pp. $445-461$.

\section{About the author}

Daria Kostecka-Jurczyk, dr hab., Associate Professor at the Faculty of Law, Administration and Economics at the Uniwersytet Wrocławski. 
